\title{
Lifestyles and Social Stratification: An Explorative Study of France and Norway
}

\author{
Gunn Elisabeth Birkelund \& Yannick Lemel
}

$\mathrm{N}^{\circ} 48$ | septembre 2013

Comparing France and Norway we will take a new approach to the discussion on lifestyles and social stratification. Instead of anchoring our definition of social stratification in predefined concepts, such as social class or status, we will empirically explore the latent patterns of social stratification and lifestyles. Our strategy allows us to investigate if social stratification is best measured by one, two or more dimensions; and then to map associated patterns of lifestyles onto this/these dimension(s). As indicators of social stratification we use education, household income and occupational status. (...) 


\section{Lifestyles and Social Stratification: An Explorative Study of France and Norway}

\section{Gunn Elisabeth Birkelund \& Yannick Lemel}

Octobre 2013

\section{The authors}

Gunn Elisabet Birkelund is Professor in sociology at ISS University of Oslo. Her research interests are in social stratification and labour market studies. She was Director for Advanced Programme in Labour Studies, at the Faculty of Social Science, University of Oslo, 2006-2007.

Department of Sociology and Human Geography, University of Oslo

PO Box 1096 Blindern, 0317 Oslo, Norway

E-mail : g.e.birkelund@sosgeo.uio.no

Yannick Lemel is INSEE Inspecteur Général Honoraire. He was director of the CREST's laboratory of Quantitative Sociology from 1993 to 2008. He was Director of: the INSEE's Parisian Economic Observatory from 1988 to 1993 . He is a researcher associated with GEMASS. His research interests are in social stratification and the sociology of inequalities.

CNRS, University of Paris IV - Sorbonne (GEMASS),

190 avenue de France, 75013 Paris, France

E-mail : lemel@ensae.fr

\section{The text}

An earlier version of this paper was presented at a meeting of The ISA's Research Committee on Social Stratification and Mobility, Yale University, 2009, at the SOCCULT seminar, Centre Maurice Halbwachs, 2009. We thank participants at these meetings for valuable comments. This version was first published by the GEMASS in February 2012 as GeWop-3. A version of this article was published in Gunn Elisabeth Birkelund (ed.), Class and Stratification Analysis (Comparative Social Research, Volume 30), Emerald Group Publishing Limited, p.189-220.

This paper is published by the Groupe d'étude des méthodes de l'Analyse sociologique de la Sorbonne (GEMASS - CNRS, Paris Sorbonne, FMSH) in Paris, under the cover of the Fondation Maison des sciences de l'homme's collection of working papers.

\section{Citing this document}

Gunn Elisabeth Birkelund \& Yannick Lemel, Lifestyles and Social Stratification: An Explorative Study of France and Norway, FMSH-WP-2013-48, GeWoP-3, octobre 2013.

C Fondation Maison des sciences de l'homme - 2013

Informations et soumission des textes :

wpfmsh@msh-paris.fr

Fondation Maison des sciences de l'homme 190-196 avenue de France

75013 Paris - France

http://www.msh-paris.fr http://halshs.archives-ouvertes.fr/FMSH-WP http://wpfmsh.hypotheses.org
Les Working Papers et les Position Papers de la Fondation Maison des sciences de l'homme ont pour objectif la diffusion ouverte des travaux en train de se faire dans le cadre des diverses activités scientifiques de la Fondation : Le Collège d'études mondiales, Bourses Fernand Braudel-IFER, Programmes scientifiques, hébergement à la Maison Suger, Séminaires et Centres associés, Directeurs d'études associés...

Les opinions exprimées dans cet article n'engagent que leur auteur et ne reflètent pas nécessairement les positions institutionnelles de la Fondation MSH.
The Working Papers and Position Papers of the FMSH are produced in the course of the scientific activities of the FMSH: the chairs of the Institute for Global Studies, Fernand Braudel-IFER grants, the Foundation's scientific programmes, or the scholars hosted at the Maison Suger or as associate research directors. Working Papers may also be produced in partnership with affiliated institutions.

The views expressed in this paper are the author's own and do not necessarily reflect institutional positions from the Foundation MSH. 


\section{Abstract}

Comparing France and Norway we will take a new approach to the discussion on lifestyles and social stratification. Instead of anchoring our definition of social stratification in predefined concepts, such as social class or status, we will empirically explore the latent patterns of social stratification and lifestyles. Our strategy allows us to investigate if social stratification is best measured by one, two or more dimensions; and then to map associated patterns of lifestyles onto this/these dimension(s).

As indicators of social stratification we use education, household income and occupational status, and to measure lifestyles we use data from two surveys on lifestyles and cultural consumption (Media og kulturforbruksundersøkelsen 2004, Norway and module Pratiques culturelles et sportives, Enquête Permanente sur les Conditions de Vie 2003, France). We limit our analysis to occupationally active respondents, 20-64 years of age.

We would expect our findings to differ somewhat between the two countries, but given that social stratification is a pervasive element of all modern societies, we would also expect to find common empirical patterns that may be of relevance to the way we conceptualize lifestyles and social stratification.

\section{Keywords}

social stratification, France, Norway, cultural consumption, social spaces

\section{Styles de vie et stratification sociale. Une étude exploratoire de la France et de la Norvège}

\section{Résumé}

En comparant la France et la Norvège, nous adopterons une nouvelle approche en matière d'étude des modes de vie et de la stratification sociale. Au lieu d'ancrer notre approche dans des concepts prédéfinis, classe sociale ou statut, nous adopterons une démarche empirique. Nous examinerons d'abord la dimensionnalité des espaces sociaux, nous permettant de décider si la structure sociale est mieux représentée par une, deux ou plusieurs dimensions. Nous cartographierons ensuite les modes de vie sur cette / ces dimension(s).

Comme indicateurs de position dans le système de stratification sociale, nous utilisons l'éducation, le revenu du ménage et le statut professionnel. Pour étudier les modes de vie, nous utilisons les données de deux enquêtes sur les «modes de vie et de consommation culturelle « (Media og kulturforbruksundersøkelsen) 2004 enNorvège et le module « Pratiques culturelles et sportives », Enquête Permanente sur les conditions de Vie 2003, pour la France. Nous limitons notre analyse aux personnes actives, de 20 à 64 ans.

Nous nous attendons à ce que nos résultats diffèrent quelque peu entre les deux pays, mais étant donné que la stratification sociale est un élément omniprésent de toutes les sociétés modernes, nous nous attendons aussi à trouver un modèle commun qui pourrait être pertinent pour conceptualiser les modes de vie et de la stratification sociale.

\section{Mots-clefs}

stratification sociale, France, Norvège, espaces sociaux, consommation culturelle 


\section{Content}

Introduction $\quad 5$

Social stratification $\quad 5$

Lifestyles 5

Why compare France and Norway? $\quad 6$

A two-fold explorative design $\quad 6$

Some theoretical points 6

$\begin{array}{ll}\text { The dimensions of social stratification } & 6\end{array}$

$\begin{array}{ll}\text { Cultural activities \& lifestyles } & 7\end{array}$

Cultural niches $\quad 7$

Data and methods $\quad 7$

$\begin{array}{ll}\text { Surveys } & 7\end{array}$

Variables $\quad 8$

$\begin{array}{ll}\text { Methods } & 9\end{array}$

Social stratification - France and Norway compared 9

Lifestyles - France and Norway compared 11

France 12

$\begin{array}{ll}\text { Norway } & 14\end{array}$

Comparing the full set analysis with the reduced set in Norway 16

Comparing lifestyle clusters - France and Norway 16

Mapping lifestyle clusters onto Social Structure 16

$\begin{array}{ll}\text { Conclusion } & 18\end{array}$

$\begin{array}{ll}\text { References } & 20\end{array}$ 


\section{Introduction}

ociological research on lifestyles and cultural consumption usually builds on theoretically predefined concepts of social stratification, be it social class or social status, and then empirically correlates this/ these concepts with lifestyle patterns. Different patterns have been identified: Bourdieu argues in favor of the so-called homology-thesis by correlating distinctions based on lifestyles and cultural consumption with economic and cultural capital (Bourdieu [1979] 1984). According to this thesis, higher class individuals distinguish themselves by consuming high-brow culture, such as opera, classical music and theatre, whereas, on the other hand, the lower class individuals prefer watching movie at the TV and listening pop-music.

On the other hand, recent Weberian inspired research across several countries have found a more differentiated lifestyle pattern, supporting the omnivore thesis, as advocated by Petersen (1992) (see also Chan (ed.) 2010). According to this thesis, people interested in culture are omnivores, i.e. they go both to the cinemas and the opera/theatre.

Whereas patterns of lifestyles in these studies are explored empirically, these approaches rely on theoretical definitions of social stratification, be it social class or status. Social structure is conceptualized in a number of ways, and within the literature on social class and stratification, there are (at least) two schools of thought: One emphasizing the uni-dimensionality of social stratification, such as the socioeconomic occupational scale (Blau and Duncan 1967), the international scale of occupational prestige (Ganzeboom et al. 1992) and the social status scale recently developed by Chan and Goldthorpe (2007). Others emphasize the multi-dimensionality of social stratification: For Bourdieu, social space comprises two dimensions, one on capital volume, and the other "capital composition" (Bourdieu 1979). The class schemes of Wright (1985) and Eriksen \& Goldthorpe (1992) are theoretically different, yet also these schemes conceptualize social stratification as multidimensional.

In this paper we take a different approach. Instead of relying on theoretically predefined concepts we will empirically explore the latent patterns of lifestyles and social stratification. By doing so, we take a pragmatic view on the dimensionality of social stratification, i.e. we are open to including more than one dimension, if necessary. Lifestyles can be defined in many ways; we will here refer to life styles and cultural activities interchangeably, using information on cultural activities as our basis for defining lifestyle groups. Thereafter, we will merge these patterns to visualize the association between lifestyle groups and social stratification.

Our study is based on two countries: France and Norway, including only economically active citizens between 20-64 years of age. Norway, a social-democratic country outside the European Union, with a more compressed income distribution than France, now one of the wealthiest countries in the world, has traditionally been poorer than France. France, a continental country with an old European history, has traditionally been more marked by aristocracy and bourgeois habits and cultures. Looking at lifestyle patterns and social stratification, we will explore what is common, what is unique and what co-varies between these countries (cf. Birkelund 2006, Coulangeon and Lemel 2009). Our methodology is explorative, yet our research questions can be summarized as follows:

\section{Social stratification}

Our research design allows us to explore empirically, for France and Norway separately, if social stratification is best measured by one, two or more dimensions. We would expect our findings to differ somewhat between the two countries, but given that social stratification is a pervasive element of all modern societies, we would also expect to find common empirical patterns that may be of relevance to the way we could theoretically conceptualize social stratification. Without theoretically predefined concepts of social stratification what patterns of social stratification are found in the two countries?

\section{Lifestyles}

Are lifestyles groups easier to differentiate in France than Norway? There is a longstanding discussion in sociology about how one best should measure cultural consumption and lifestyles. Should one study "tastes" or "activities"? Obviously, what people do might not reflect what they would do if they were free from various types of constraints. Without denying the interest in studying tastes, we may underline that their 
assessment requires complex and costly observation protocols - very seldom implemented in practice. Our focus of interest is in what people say they do. As such, we will use the activities as our starting point and try to single out groups of people who appear to engage in similar activities and share the same sort of lifestyle.

These are questions we may begin to answer in this paper, using data from two national representative surveys (2003/2004).

\section{Why compare France and Norway?}

We are comparing two European countries, with some similarities and some differences. Both countries have relatively low levels of economic inequality, with a Gini index of 25.8 for Norway and 32.7 for France. ${ }^{1}$ Whereas France is located in the centre of the EU, and one of the first countries to initiate European collaboration, Norway is not a member of EU (yet an active member of European Economic Agreement), and located at the Northern periphery of Europe. The two countries belong to different welfare state regimes, one continental and one social democratic (EspingAndersen 1990). Looking at cultural dimensions developed by Hofstede ${ }^{2}$ France and Norway have about the same scores on a scale that measures individualism versus collectivism, yet the two countries differ on other dimensions, in particular an index measuring power distance, an index measuring masculinity and an index measuring uncertainty. Given the economic, political and cultural differences between Norway and France we find it interesting exploring the patterns of social stratification and people's lifestyles in these countries.

\section{A two-fold explorative design}

Our analytical strategy is first constructing empirically the dimension(s) of social stratification in France and Norway separately, and then comparing them. Second, we construct the latent patterns of lifestyles in France and Norway separately, and then compare similarities and differences. Third, we will be mapping life-styles onto social spaces, for France and Norway separately.

1. http://en.wikipedia.org/wiki/List of countries by income equality (read 17.03.2009)

2. http://www.geert-hofstede.com/geert hofstede resources.shtml (read 17.03.2009).

\section{Some theoretical points}

Weber identified social stratification as a multidimensional concept, including social class, status and power as vital dimensions in modern societies (Weber 1978). At the most general level, following Peter Blau's discussion on social structure (Blau 1977), in order to explore social inequality, we should include the whole set of the usual socio-demographic characteristics, such as age, generation, gender, ethnicity, education, income and wealth, occupation and urbanization of the place of residence and so on. However, our interest here lies with the main variables that underlie the usual sociological representations of the structure of social stratification, here are several ways to measure social stratification, and our explorative approach here is open to several dimensions.

\section{The dimensions of social stratification}

In The Distinction, Bourdieu determines the social positions through their place in a bi-dimensional social space defined by the "volume of global capital" and the composition of capital, using economic and cultural capital as the main determinants of the social space. Actually, the social space thus developed is a particular variant of Blau's social spaces, which are made of homogeneous cells of various socio-demographic characteristics (McPherson \& al., 1991), and the number of dimensions initially generated to define the space reflects the number of variables included in the analysis. For analytic purposes, however, one usually decides including only a reduced set of dimensions, in order to detect the most important dimensions of the social space. ${ }^{3}$

The Bourdieusian model relies on a social space essentially based on the combination of two characteristics: the educational level and the resource level of the individuals. Thus it could be argued that theoretically the Bourdieusian social space is a two-dimensional social space. Given the complexities in measuring cultural and economic capital, however, it is often necessary including several variables, thereby generating initially more than two dimensions. In this paper, we limit ourselves to include education, income, and occupational status as measures of stratification. Ideally, we would also have wanted to include more variables. In particular, if we were to follow

3. This usually means dropping the dimensions generated last, with the lowest Eigenvalue/variance. 
a usual interpretation of Bourdieus' design, which were never clearly defined by himself (Prieur et al. 2008: 49), we should have included a larger number of other variables. We will later include gender, age and residence (rural/urban) to identify the most common profiles of the lifestyles groups.

\section{Cultural activities \& lifestyles}

It seems clear by now that a strict version of the homology-thesis associated with Bourdieus work do not receive empirical support in modern analysis of lifestyles and social stratification. Admittedly, it would most likely be possible; using qualitative data, identifying a group attending only high-brow cultural events, yet this group is too small to be detected in survey data representing a sample of the population in a country. In addition, there is no convincing argument that this group has political power. For instance, images of female, middle aged teachers could come to mind; women interested in consuming cultural products such as reading books, going to the theatre and to art exhibitions, with without, it seems, the power to define what constitutes 'high-brow' culture.

The omnivore-thesis is still being discussed, and though most empirically oriented research, using representative surveys of the populations do find support for this thesis, there are still many questions about its validity and content (Nyhammer 2008, Chan (ed.) 2010). Bluntly put, the thesis, first advocated by Richard Petersen (1992) argues there is a group of active consumers in modern societies that are open to various sorts of cultural expressions, including both mass cultural events (such as going to the cinema) as well as elitist high-brow culture (such as going to the opera). Certainly, more people go to the cinema than the opera, but the findings support the omnivore thesis: those that do go to the opera (which are relatively few) also go to the cinema, and not only that, they also go more frequent to the cinema than others do. Thus, they are omnivores.

\section{Cultural niches}

Life-style could work as an identity marker, and we will also be interested in the composition of the lifestyles groups, are they on average old or younger, female of male dominated, etc. One may argue that modern societies are filled with small niches of sub-cultural groups, identifying with, interested in, and particularly also trying to develop specific types of sub-cultural lifestyles. In particular, young people are often actively engaged in what we may call cultural sub-groups, such as the rock and rollers in the 1950s, and the internet nerds in the 1990s. Some of these groups may also have a political agenda, which would usually be changing the establishment; as when the green activists practice a modest lifestyle to make the modern consumer society more environmental friendly. The existence of these niches is an interesting phenomenon, yet exploring them is beyond the scope of this paper. Lifestyle groups thus identified would probably be too small to be detected in survey data. Our data allows us to distinguish people who are interested in for instance music from people who are not, yet not what kinds of music they listen to.

In a nearby vein, the literature on lifestyle is not always clear on the following point: are lifestyles the prerogative of a limited number of persons or could everyone be characterized by their lifestyle? Surely Bourdieu examined population data (for a recent example: Benett, 2009). This is not the case of all researchers, though. Like Bourdieu, we adopt here an approach which deals with the whole population, thus we will statistically classify all respondents into lifestyles clusters. Whether these clusters also are "cultural groups" in the sense of comprising members with sub-cultural group awareness is beyond this paper to explore. ${ }^{4}$

\section{Data and methods}

\section{Surveys}

We use two surveys, one from each country, on lifestyles and cultural activities. For France, we use the survey on Cultural and sports participation which is part of the May 2003 issue of the The Continuous Survey of Living Conditions carried out three times a year by the INSEE, the French statistical office. The random sample is representative of individuals aged 15 and over who live in households in metropolitan France. Response rate: 67 percent.

\footnotetext{
4. Lifestyles could also be a product of people's opportunities, as when rural citizens lack access to opera performances. However, in both countries, the authorities have implemented an active policy for culture dissemination. In Norway, Riksteateret, and Rikskonsertene are established by the Norwegian Parliament to provide live theatre and music to rural citizens. In France, an active policy for "Culture" dissemination through the country was pursued by all the successive governments since that of the General de Gaulle and his culture minister, André Malraux.
} 
For Norway, we use the survey Kultur og mediebruksundersøkelsen 2004 (The 2004 Survey on Cultural and media consumption), which was carried out by Statistics Norway. The random sample is representative for the Norwegian population ages $9-79$ years. ${ }^{5}$ Response rate 70 percent.

\section{Variables}

\section{Social stratification variables}

In order to construct the social structure, we need valid information on education, income and occupation. The Norwegian data only contains occupational information for the occupationally active respondents; thus for comparative purposes we have limited both the French and the Norwegian samples to including only occupationally active individuals between 20-64 years, excluding students, housewives, unemployed and retired people. Thus our French sample comprises 3744 individuals and the Norwegian sample 993. We will discuss/try to evaluate the consequences of this selection at the end of the paper.

Education will be measured as the number of years necessary to get the highest diploma people have. Given our interest in cultural activities, not tastes, we are interested in the economic opportunities to undertake cultural activities. We therefore have constructed a measure of household income (per capita), and given the skewed distribution, we use the $\underline{\mathrm{Log} \text { of household income per capita. }}{ }^{6}$ Occupational status is measured according to Chan and Goldthorpe's social status scale (Chan and Goldthorpe 2007, Lemel 2006, Chan et al.2010).

\section{Cultural activities variables}

The questionnaires in both surveys include items on a variety of cultural practices, such as reading, listening to music, attending festivals and other cultural outings, television viewing, artistic hobbies, going to the cinema and watching sports

5. The young age of some respondents in the Norwegian survey is related to a special part of the survey asking children and teenagers about their use of media, computers, internet, etc.

6. One Norwegian household with annual income higher than NOK 8 million is excluded. Thereafter, Norwegian households where information on income is missing ( $N=65)$ are imputed with the average income value. In the French data, the French statistical office (INSEE) has preliminary edited the data before they are issued for research purposes. This also means imputing income for households without information on income, using an imputation formula for income. activities. Generally, the questions are retrospective in nature, asking about the practice of an activity over the past twelve months (professional and school obligation excluded). The questionnaires used in the two surveys are, however, not identical. In particular, the French survey includes a large number of questions on sport activities, partly due to the French political authorities wanting to map the distribution of sports activities in the French population. On the other hand, the Norwegian survey includes questions about time spent on internet, video and DVD; questions not included in the French questionnaire. Mainly for this reason, we will perform two sets of analysis for cultural activities; one using a small set of variables that are common in both questionnaires (as similar as obtainable in these surveys; there are still differences in the way some of these variables are worded and the framing of answers). ${ }^{7}$ Secondly, in addition to the common variables we add country specific variables, thus obtaining measurements of a larger set of cultural activities (more in the French than the Norwegian survey).

For the first set we include 11 variables, some measuring cultural activities taking place outside the home: going to the opera, theater, ballet, concert, art exhibition, museum, sports events, movies and visiting a library, others (usually) taking place inside the home: reading books, watching TV, reading newspapers. These variables measure the time the respondents spent on the cultural activity the last time they performed it, or the number of times they have undertaken a particular cultural activity the last 12 months. We therefore can utilize metric strategies of analysis.

For the second set we include 44 variables for France, and 21 variables for Norway. Again, the variables measure a number of different cultural activities, in particular related to sports for France. ${ }^{8}$ The inclusion of more variables allows us to identify more precise lifestyle clusters in the French data which we will demonstrate later.

7. Generally, in the French questionnaire, the respondents are asked about a specific activity and are allowed to answer that they engaged in this activity never, seldom, from time to time, or regularly over given period of time (last 12 months, or last week). The same question in the Norwegian questionnaire allows respondents to report how many times they were engaged in this activity over a given period of time (last 12 months, or last week). We have used these metrics as they are.

8. Table A1 (Appendix) show the frequencies of respondents attending these activities, separately for France and Norway. 


\section{Omitted variable bias?}

The limitations in the questionnaires have unfortunate consequences for our analysis. Our results are limited to the variables included, thereby possibly being unable to identify important lifestyle clusters defined around other cultural activities than measured here. We run the risk of identifying latent lifestyle clusters particular to each country that are an artefact of different, country specific, variables. How precisely should the activities be defined? We might have chosen to limit the scope of investigation to a few domains, but, in this way, we could not have a more general view, which is precisely our goal. We have therefore tried to cover the various domains examined in the survey. We cannot exclude the possibility that the conclusions we will draw are partly artifacts of the activities we have chosen.

\section{Methods}

Various methods can be considered to group individuals presumably having similar lifestyles. One can choose certain practices characterized to be typical of a lifestyle. Thus, for instance, activities like visiting museums and going to classical music concerts are thought to be the distinctive mark of a "highbrow lifestyle". This method allows the definition of the lifestyle clusters through their predefined construction, but its drawbacks are its arbitrariness and the risk of giving too much importance to marginal phenomena. In this paper, we favour an alternative approach. We have first performed separately principal component analysis to identify the latent dimensions of social stratification. Second, looking at lifestyle patterns, we have used the K-means method ${ }^{9}$. Results could be dependant of the specific clustering method implemented. Some sensitivity analyses were done in the French case (Coulangeon \& Lemel 2009). In this case, it appears that a three cluster solution on lifestyle groups is a stable one, rather independent from the clustering techniques used. The results are almost the same no matter if we proceed by describing the observations through the 44 detailed practice indicators or through the 2 or 3 synthetic indicators built up by a main component analysis. Results are also the same if we use other clustering technique than the

9. In this method, the three groups are created by an iterative procedure on the basis of randomly selected "seeds". Observations are described by synthetic indicators built up by PCA. As usual, the PCA is based on the correlations matrix of the variables included.
$\mathrm{K}$-mean method. So, the K-means method was implemented systematically for creating three groups in each case.

The rest of the paper is organized in the following way: In the first part we apply Principal Component Analysis (PCA) on the social structure variables for France and Norway, respectively. We then continue, using PCA and Cluster analysis on the cultural activity variables, again for France and Norway separately. We then merge the two analyses to map lifestyle clusters onto the social structure.

\section{Social stratification - France and Norway compared}

In both countries we find a latent pattern describing the manifest variables education, (log) household income and occupational status. The pattern is very similar for the two countries, see Tables 1 and 2, and Figures 1 and 2, and, we argue, mainly bi-dimensional. In both countries, all three variables have positive loadings on the first dimension: education, occupational status and household income, and, in both countries, the second dimension is mainly defined by differentiation - or substitution - in composition, that is, between (log) household income on the one hand, and education and occupational status on the other. In the third dimension education and occupational status are opposing each other, yet this dimension is less important statistically (lower eigenvalues). Thus, the social structure/social space in France and Norway is mainly bi-dimensional.

Looking at the loadings of each variable onto the latent dimension, the first dimension may be interpreted as a proxy for a socio-economic dimension. Positive values on this dimension are associated with high education, social status and income, whereas negative values are associated with low education, social status and income. This dimension resembles in many ways what Bourdieu named the"global capital" dimension.

The second dimension is orthogonally related to the first dimension (i.e. the two dimensions are statistically independent). The second dimension is positively related to household income, whereas education and status have negative loadings on it, in both countries. This dimension resembles what Bourdieu called "capital composition". 
Figure 1 Social space - France - CA (Axis $1 \& 2$ ).

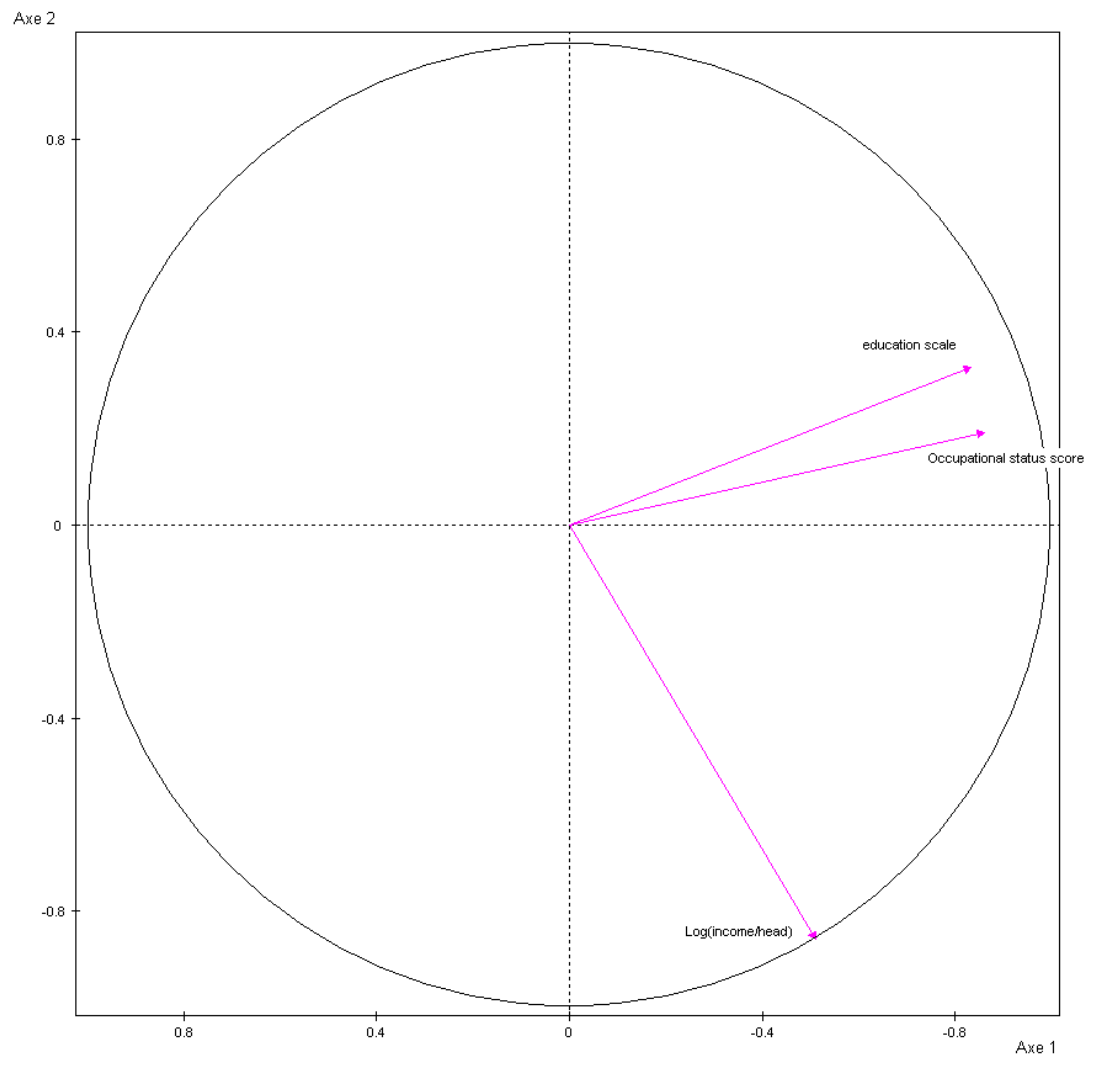

Figure 2 Social space - Norway - CA (Axis $1 \& 2$ ). (Economically active $20-65$ years)

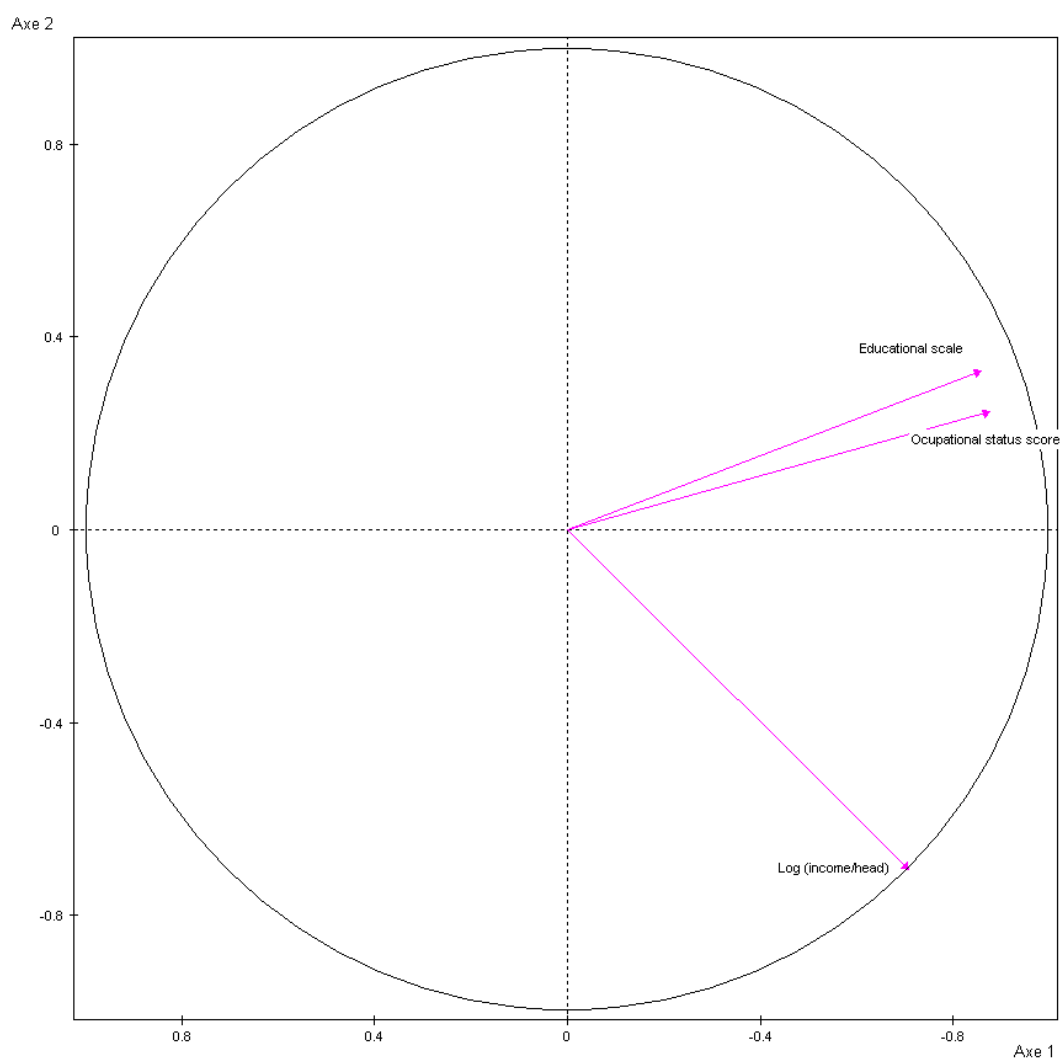

Fondation Maison des sciences de I'homme - 190 avenue de France - 75013 Paris - France http://www.msh-paris.fr - FMSH-WP-2013-50 
Table 1 Social space - France CA (Loadings). (Economically active $20-65$ years)

\begin{tabular}{|c|c|c|c|}
\hline \multirow[b]{2}{*}{ Loadings } & \multicolumn{3}{|c|}{ Component } \\
\hline & 1 & 2 & 3 \\
\hline Education & 0,61 & $-0,41$ & 0,68 \\
\hline $\begin{array}{l}\text { Occupational status } \\
\text { score }\end{array}$ & 0,62 & $-0,30$ & $-0,73$ \\
\hline Log(Income/Head) & 0,50 & 0,86 & 0,07 \\
\hline 0 explained & 0,67 & 0,22 & 0,11 \\
\hline
\end{tabular}

\section{Table 2 Social space - Norway - CA (Loadings). (Economically active 20-65 years)}

\begin{tabular}{llcl} 
& \multicolumn{4}{l}{ Component } \\
Loadings & 1 & 2 & 3 \\
& & & \\
Education & 0,64 & $-0,34$ & 0,69 \\
$\begin{array}{l}\text { Occupational status } \\
\text { score }\end{array}$ & 0,66 & $-0,20$ & $-0,72$ \\
Log(Income/Head) & 0,39 & 0,92 & 0,09 \\
& & & \\
\% explained & 0,56 & 0,29 & 0,14
\end{tabular}

Our findings are not really surprising, given the initial positive correlation between the three manifest variables. In fact, it is precisely this positive correlation between the social stratification variables that leads to the first dimension being a 'capital' volume dimension: high values on the first latent dimension means high values on each of the three manifest variables; low values on the first latent dimension means low values on each of the three manifest variables. In all societies where the social stratification variables are positively correlated (and we know of none where this is not the case), the first dimension would pick up this correlation. Thus, obviously a Bourdieusan capital volume dimension must be the first dimension of social spaces.

For the second dimension, the actual patterns between the manifest variables may be less obvious. The second dimension is generated as a dimension orthogonal on the first. This is the fact of the methodological strategy. It is therefore constructed on the association between the manifest variables that are not related to their positive correlations, but rather to the deviations from these correlations (off-diagonal patterns, if one compares with cross tabulations). Which of the manifest variables that oppose the other(s) is an open question. Empirically, it appears that the occupational status variable is close to education, so that the two variables are therefore opposed to the economic variable. This proximity between occupational status and education deserves reflection and development, but they are outside the scope of this paper.

We have therefore generated a social space, using only three manifest stratification variables, and we will expect that such a social space will appear in all countries where the stratification variables are positively associated. We do not need any theoretical justification for this 'space', the main relevant information would be to find criteria for deciding what variables goes as stratification variables, of which, we would argue, education and income are the most important (cf the close affinity of education and occupational status).

There is an important conclusion of our results, in a comparative perspective. Even if the social structure of both countries looks very similar, the degree of status crystallization, as measured by our data, is weaker in Norway than in France: The first Eigen vector explains $56 \%$ of the variance in Norway and $67 \%$ in France (but slightly different measures of variables). This could imply a slightly less open social stratification system in France than Norway.

\section{Lifestyles - France and Norway compared}

We will now proceed to explore the life-styles in the two countries. As mentioned we have some problems of measurements related to the fact that some of these questions are not identical. Also, we are able to use more questions in the French data than in the Norwegian case (simply because the French questionnaire is larger). We have therefore decided to perform two analyses for each country, one including the full set of variables for each country, second, we only include common variables for the two countries. In both cases, we use the K-means method, doing first Principal Component Analysis for smoothing the data, then creating clusters. 


\section{France}

\section{The full set of activities -France}

Looking at France first, we do not succeed finding identity markers that clearly could identify cultural clusters (Coulangeon and Lemel 2009). Two reasons why: one, the data or the methods used are not good enough. Second: the data and methods are fine, but the reality is not as well organized as we expect, i.e. the correlation between the activity variables are rather small in the French dataset. It therefore seems difficult to define social markers in such a way that a person practicing them (for inst going to the opera) with certainty belongs to a specific group (i.e., opera-lovers). ${ }^{10}$

As said before, we nevertheless find that a three cluster solution on lifestyle groups is a stable one, rather independent from the clustering

10. This fact is another reason for introducing the two-step procedure we use here, forst PCA, then clustering. techniques used. The first dimension in the activity 'space' is a volume dimension, with high loadings from nearly all activities'. We could call this dimension an omnivore-dimension. The second component refers to sports, and especially "passive" sports, such as reading sport magazine. The exact meaning of the third component is less easy to define. For three cluster solution, we observe that whatever the activity, the indicators are weaker in cluster 1 than in clusters $2 \& 3$, except for TV watching and regional daily newspapers. The indicators are higher in cluster 2 for almost all sports activities (especially the "passive" ones), and higher in cluster 3 for all the other activities. It would thus be tempting to describe cluster 1 as "bomebodies" (or TV-addicts), cluster 2 as "sports enthusiasts" and cluster 3 as "cultured". Size of groups is 1708,1603 and 382 .

\section{Figure 3 Lifestyles - France - CA (\% Eigenvalues). (Economically active $20-65$ years)}

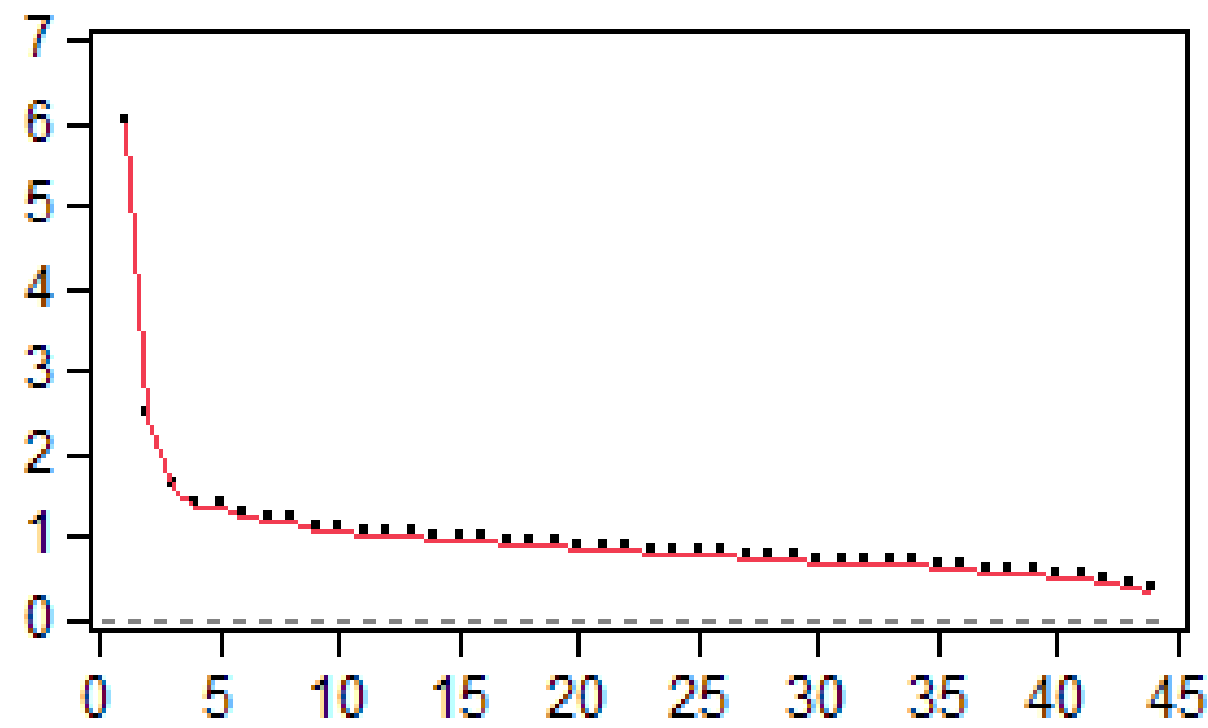


Figure 4 Lifestyles - France - CA (Axis $1 \& 2$ ).

(Economically active $20-65$ years)

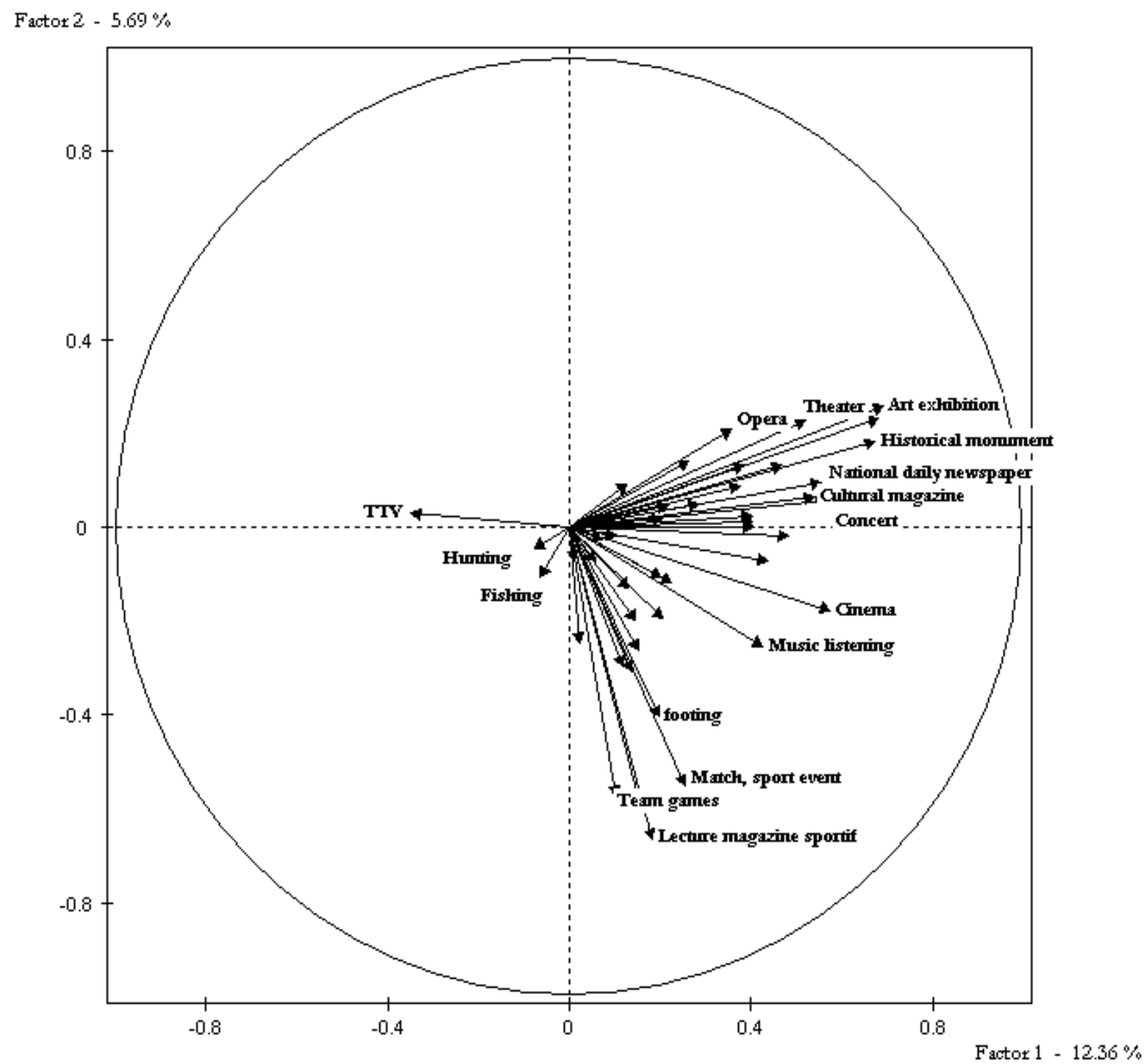

\section{The reduced set of activities - France}

We proceed by including only a limited set of 12 variables, common to both countries. ${ }^{11}$ We find, as with the full set, a first dimension which is more or less a "volume/diversity" dimension, i.e., an omnivore component. The exact meaning of the other dimensions is less easy to define. Perhaps, the second one could be interpreted as an opposition between live spectacles (i.e., watching performances with live actors/players) as compared to virtual entertainment (watching TV, movies,

11. These are: time watching TV, reading books, newspapers, number of times visiting libraries, movies, theatre, ballet, concert, opera, art exhibition, museum, and attending sport events, all measured for the last 12 months. reading books, etc.). However, attending sport events is not confirming to this pattern.

The clusters are primarily identified by the volume of activities that people undertake (i.e., the first dimension). The number of clusters to be generated seems less evident than in the previous case, where we used the "full-set" of activity variables, since any cutting along the first dimension of the CA is roughly satisfactory. For comparable purposes we selected the three clusters solution (respective size: 2535, 1063 and 146 people), the interpretation of which seems more straightforward: the first cluster is that of the "bomebodies." The last is that of the "cultured" and the second can be called the "middle-cultured". 
The "Cultured" and "middle-cultured" clusters are distinguished by the mean level activity of each activity separately, lower for the "middle cultured" cluster with two exceptions. They are not going to the opera at all, but they go to the libraries more frequent and read books more often than the "cultured" cluster. It would be advisable to check the residences of these two groups, access to the opera being obviously easier for people in very large cities, etc. We will get back to the composition of the lifestyle clusters later.

\section{Comparing the full set analysis with the reduced set in France}

The French survey includes many questions about sports activities. Thus it may not come as a surprise that, in addition to a home centred cluster and a "culturally" active cluster, we find a cluster of sports enthusiasts in the full set analysis of cultural activities. Only including common variables for the two countries implies throwing out most of these sports variables. Then, we are unable to identify a cluster of sports enthusiasts and the dominant lifestyle clusters in our data then become the home centred cluster and two culturally oriented clusters, reflecting a more traditional definition of culture, based only on variables measuring theatre, opera, concerts, art exhibitions, reading, etc.

These results demonstrate the importance of the definition of 'culture', and accordingly which variables are selected for the analysis of cultural activities.

\section{Norway}

\section{The full set of activities - Norway}

We now move to the full set of variables (21) for Norway. As in the French data, the variables are weakly correlated (in fact, weaker in Norway than France); thus it is difficult to define social markers in such a way that a person practicing them (for inst going to the cinema) with certainty belongs to a specific group (i.e., cinema-lovers). We nevertheless have generated latent components, and the first component generated by the PCA is also here a volume component, measuring most of the included cultural activities, TV apart. Thus, we can call it an omnivore component. The second component is about video, internet and music consumption, in contrast to reading and attending some highbrow events.

We decided also here to perform the clustering analysis based on the two most dominant dimensions, and to generate three life-style groups through the clustering technique: One group can be called the nerds (101 persons), since it is mainly composed of people who are actively using the internet, etc. A second group is the "readers" (219 persons), and the last one is the "inactive" (home centered) (674 persons). Thus, the characteristics of the Norwegian lifestyle clusters differ from the clusters generated in France. Also, as mentioned, the pattern is weaker than in France.

Figure 5 Lifestyles - Norway. - CA (\% Eigenvalues)

(Economically active 20-65 years)

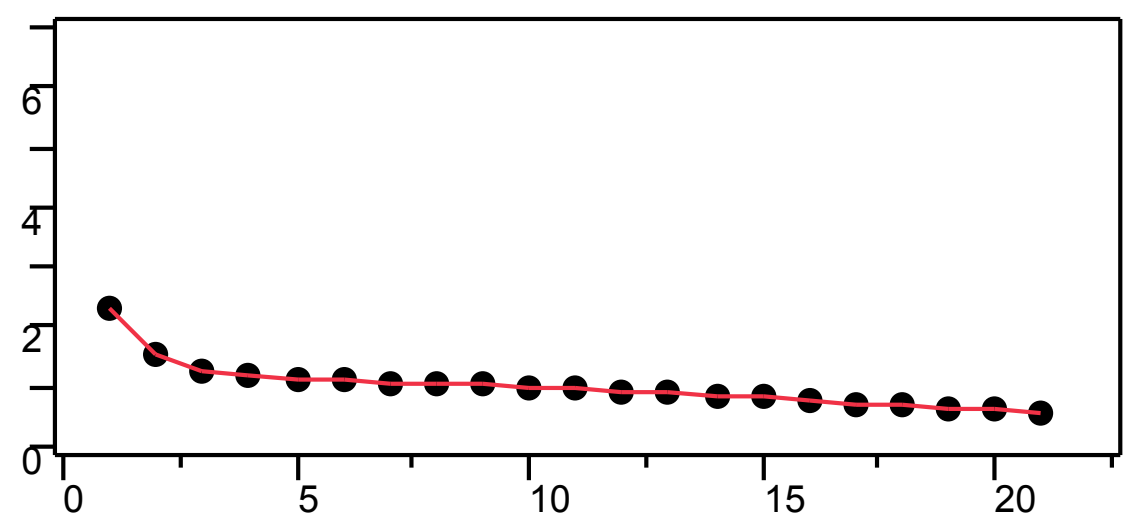


Figure 6 Lifestyles - Norway - CA (Axis 1 \& 2).

(Economically active 20-65 years)

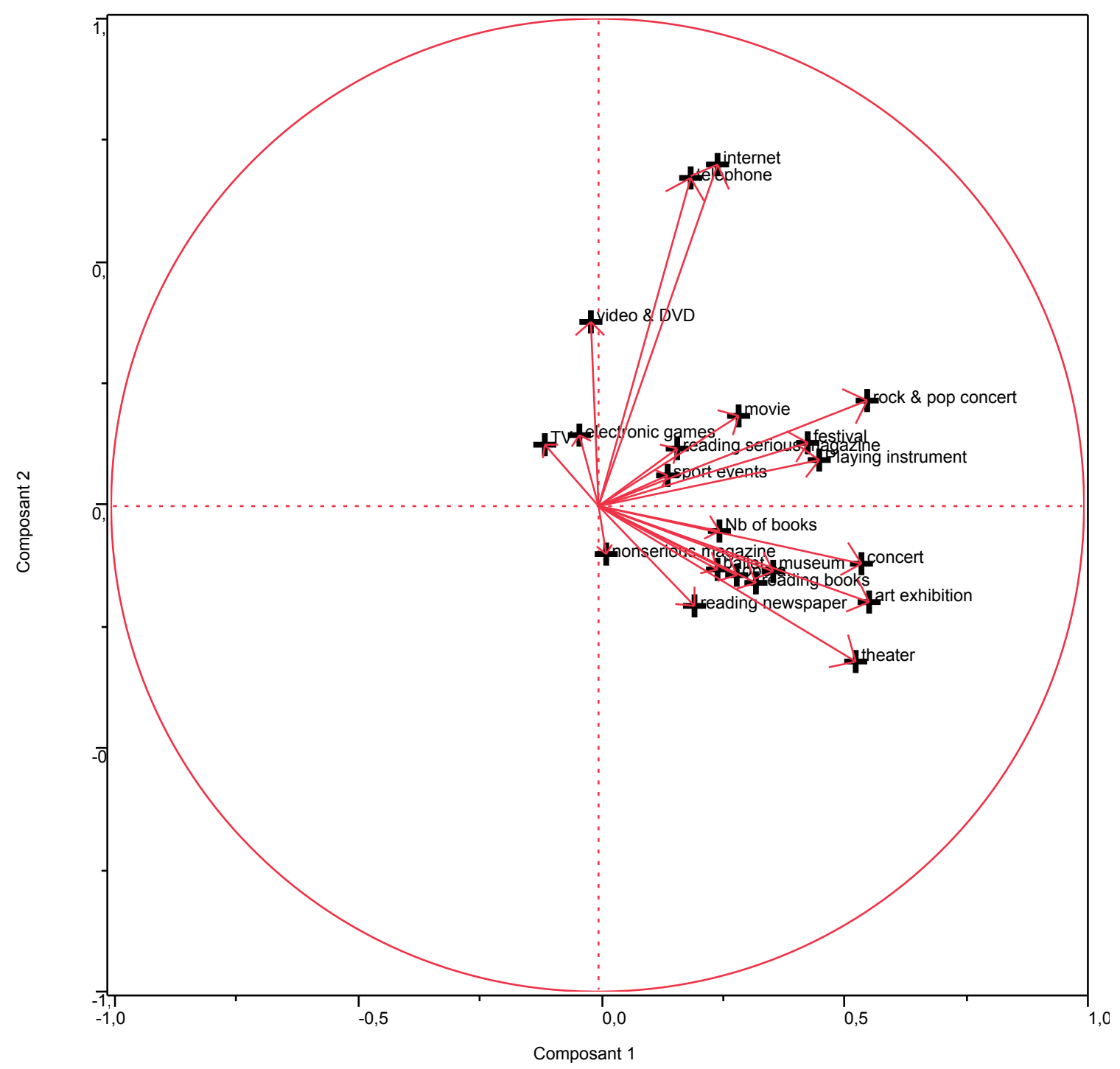

The reduced set of activities - Norway

We proceed by including only a limited set of variables, common to both countries (see footnote 10). Again, the first component is more or less a volume component, which could be called an omnivore component (TV apart). The exact meaning of the other components is less easy to define. Perhaps, the second one could be interpreted (in a Norwegian context) as an opposition between activities symbolically centered on activities at home and activities away from home.
For comparable purposes, we selected a three clusters solution (respective size: 838, 105 and 41 people). ${ }^{12}$ The first cluster is that of the "bomebodies." The two others are two types of "omnivores" or "cultured" people, one group being more involved in reading (books and newspapers), the other more involved in going out for concerts, theatres.

12. We deleted 9 outliers in this procedure. 


\section{Comparing the full set analysis with the reduced set in Norway}

In addition to media use and cultural activities, the Norwegian survey were set up to measure young people's cultural activities, therefore including questions on the use of Internet, video, DVDs, etc. in 2004, many people did not have access to internet, thus the mapping of this would seem of interest. Again we see an example of analyses generating lifestyle clusters dependent on our inclusion of different variables. In the full set analysis, we find a cluster of nerds, who spend an inordinate time on Internet. Skipping these (and other specific variables in the Norwegian questionnaire), we find, in the reduced set, clusters more as expected: one home centered cluster, and two 'cultural' clusters, differing in the time they use for reading or going out for concerts, etc.

\section{Comparing lifestyle clusters - France and Norway}

Looking at the full set of variables, we need more components to describe patterns of activities in Norway than in France. This is so despite the fact that there are fewer variables in the Norwegian full set than the French. This implies that the cultural activities of the Norwegian people are less structured, i.e. more individualistic, compared to that of the French. Of course, we must be cautious because our data are not completely comparable; the samples are small and so on. Nevertheless, this is the conclusion with the data we have.

Using only the reduced set of variables, we - again - see that the patterns are stronger in France than Norway. Nevrtheless we area ble to identify clusters in both countries, and we find rather similar lifestyle clusters in France and Norway: two clusters that are "cultural" in their activities, and one cluster of home sitters. In both countries the largest cluster is the home sitters.

We will now proceed by mapping the lifestyle clusters onto the social space we have constructed, for France and Norway separately.

\section{Mapping lifestyle clusters onto Social Structure}

Building on previous analysis, we have saved the scores of each individual on the two latent dimensions, capital volume and "capital composition", defining the social space in France and Norway, respectively. ${ }^{13}$ Using these dimensions, we have rotated them 90 degrees so that the "global capital" dimension is vertical, and the "capital composition" dimension horizontal (to obtain a similar picture of social space as Bourdieu used). We will first use the activity clusters as defined by the full set variables in each country. Figures 7-8 show the mapping of the French activity groups as defined by the full and then reduced set of cultural activity variables on the social space; whereas Figures 9-10 show the mapping of the Norwegian activity groups as defined by the full and then reduced set of cultural activity variables in the Norwegian survey on the social space. The left part in each figure shows the distribution of respondents in the social space, and we see that the French sample is more dispersed along the "global capital" axis (the vertical axis) than the Norwegian sample. This finding is in line with established knowledge about an overall lower level of inequality in Norway than most OECD countries.

The right part of each figure show the mapping of the lifestyle clusters onto the social space. If we had included all individuals, the groups would be more scattereded in social space and difficult to separate (cfr earlier comments about the fuzziness of the clusters and their boundaries). We have therefore drawn lines including 50 per cent of the individuals in each cluster.

13. Another way would be to construct the social space using indicators of the two dimensions. Since the first part of our analysis has shown the two dimensions to be very similar in the two countries, we can construct the indicators of «capital volume " and «composition of capital» in similar ways for both countries: Capital volume would then be defined as [(occupational status indicator + indicator of educational level)/2 ] + indicator of economic level). Composition of capital could be defined as (occupational status indicator + indicator of educational level) $/ 2$ - indicator of economic level. We have tried both, and the correlation between the two indicators of the first dimension, as well as the two indicators of the second dimension, is in both cases approximately 0.8 or 0.9 . 
Figure 7 Mapping three lifestyle groups onto social structure France - PCA - Full set

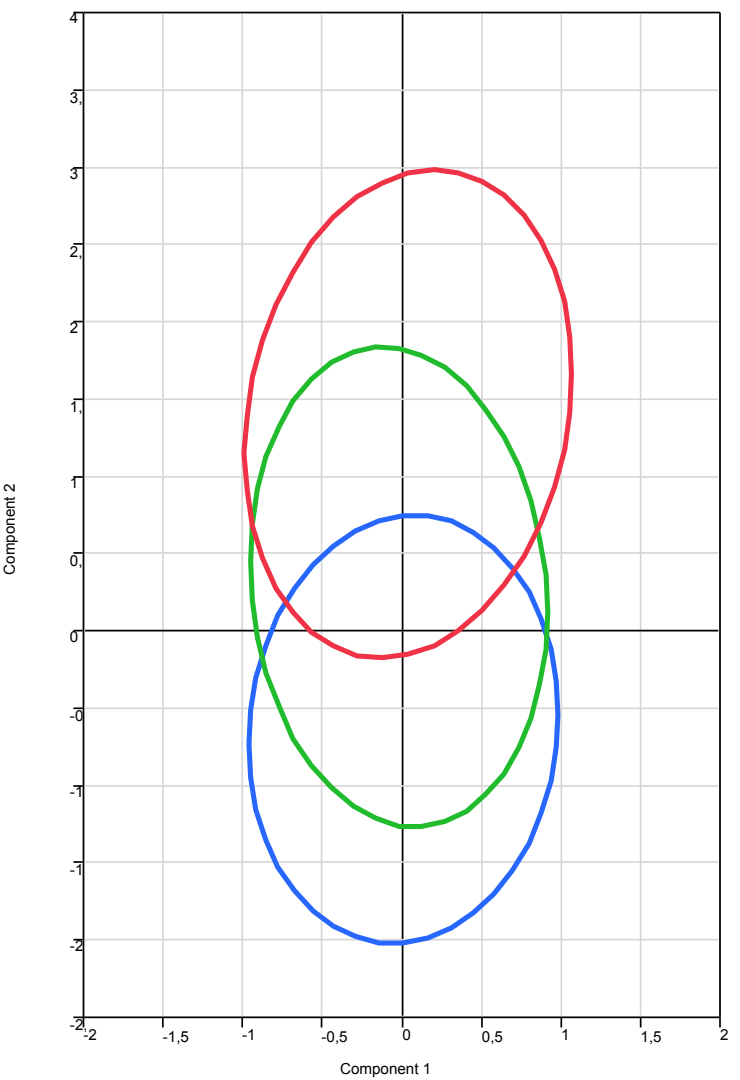

Figure 9 Mapping three lifestyle groups onto social structure - France - CA - common set

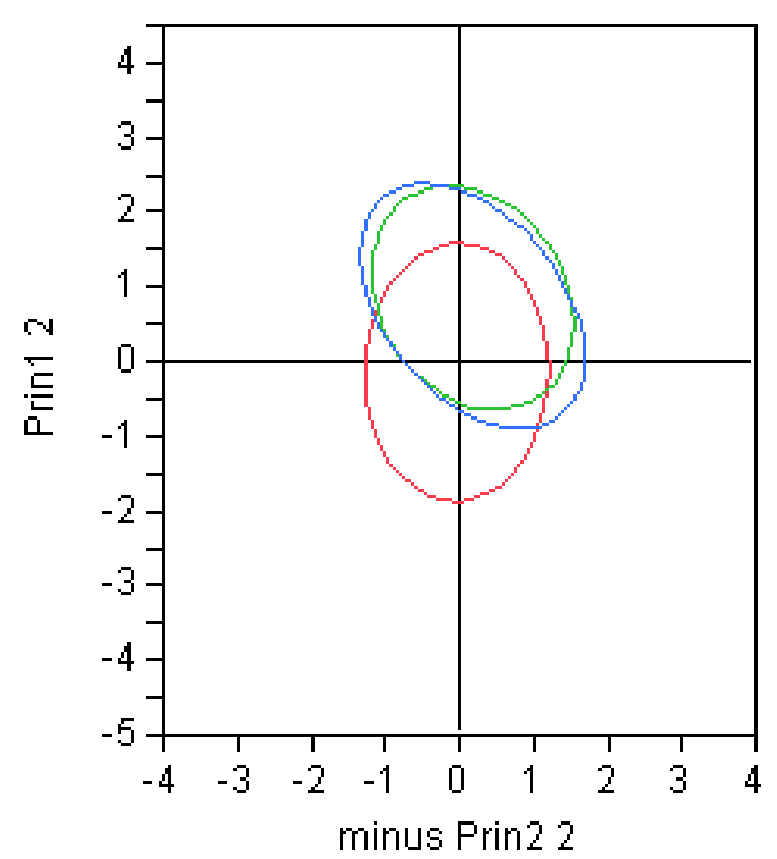

Figure 8 Mapping three lifestyle groups onto social structure Norway - CA - Full set

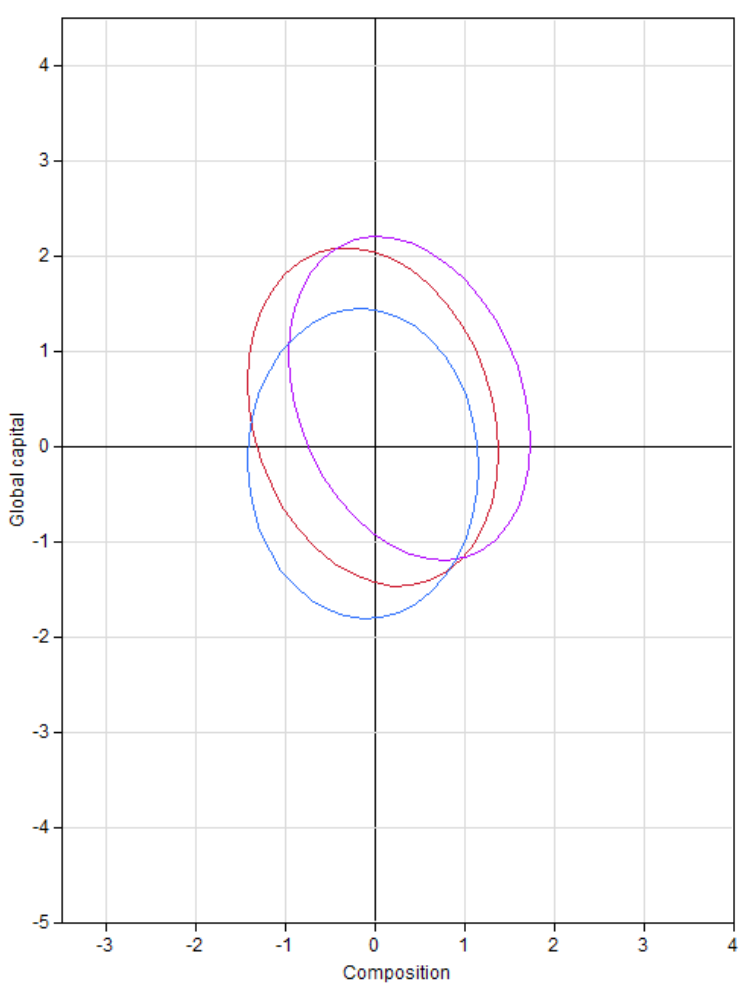

Figure 10 Mapping lifestyle groups onto social structure - Norway - CA common set

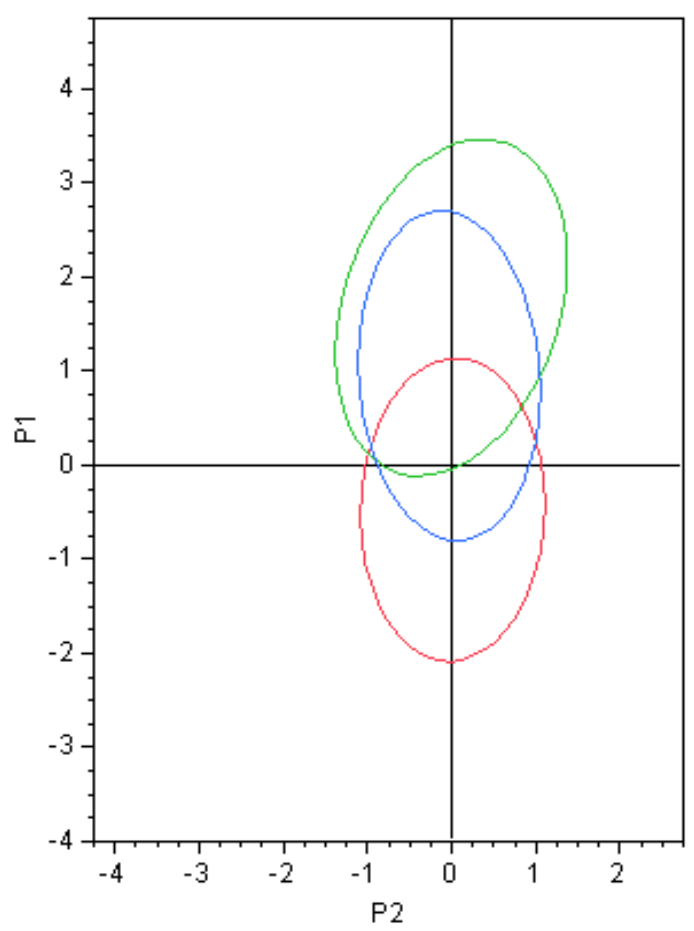


We note that in the French graphs the lifestyle clusters are more dispersed along the "global capital" axis (the vertical axis). This is the case both for activity groups as defined by the full set of variables (Figures 7 and 9) and activity groups as defined by the reduced set of variables (Figures 8 and 10), implying that lifestyles is stronger associated with "global capital" in France than in Norway. Also, we see no differences in lifestyles associated with the composition of capital (the horizontal axis), and this is the case for both countries.

We also note that the degree of overlap of these ellipses within the social space is great. This means the social positions are not corresponding directly with the life-style groups (a strong correspondence would be in line with the homology thesis). In addition, the degree of overlapping seems to be stronger in the Norwegian data than in the French data.

As argued earlier, in a Blau space we would ideally included a number of relevant variables that are left out here. Particularly three characteristics seem important for a better understanding of the activity groups: who they are in terms of gender and age, and what access they have to cultural events, such as opera, etc.

For instance, analysis not shown here tells us that in the clusters are gendered: in the Norwegian data, looking at average figures we find that the cluster we have called the nerds are mainly men (70 per cent male) and slightly younger (36 years) than the others. The cluster we called the readers are mainly women (60 per cent women) at nearly 40 years of age. The cluster we called the home sitters, is a bit older (41 years of age) and 50-50 per cent men and women. There are no differences between the clusters in their occupational status and household income, and small differences in their average educational level, again a reflection of the lack of association between the social stratification variables and lifestyle clusters. In the French case, the clusters are gendered too: for instance we find that the cluster we have called the "sports enthusiasts" are mainly men (61 per cent male) and slightly younger (41 years) than the others. As in Norway, there are no differences between the clusters in their occupational status and household income, but differences in their average educational level is a bit higher.
The heterogeneity of the lifestyles clusters adds more complexity to our understanding of the association between social stratification and cultural activities. Certainly, gender and age are important for peoples' lifestyles.

\section{Conclusion}

Using an explorative approach to social stratification and lifestyle patterns, we have compared two countries. We cannot exclude the possibility that the conclusions we draw are partly artefacts of the activities we have chosen to examine. Let us summarize our findings: We were interested in lifestyles and social stratification - what is learnt by this explorative exercise?

In both France and Norway we found common patterns of social stratification - two dimensions in each country, as constructed by the stratification variables education, occupational status and household income. We have argued that the main dimension of this social space, often called the volume of capital, or "global capital", is simply a natural product of the positive correlation between these stratification variables, and the method used to generate the first latent dimension. For the second dimension, the actual patterns between the manifest variables may be less obvious. Empirically, it appears that the occupational status variable is close to education, so that the two variables are therefore opposed to the economic variable. Thus, for both countries, we are able to generate a social space that resembles Bourdieu's proposal.

Second, looking at the cultural activities of the respondents in our surveys, we find, depending on how many activity variables we include, important similarities and differences. Using all country specific variables, we identify different lifestyle clusters in the two countries, reflecting differences in the questionnaires. For France, a cluster of sports enthusiasts reflects the large section with questions about sports; for Norway, a cluster of nerds reflects the large section with questions about internet use. When we use only the questions that are common to both countries, we are left with the more traditional measures of cultural activities, such as going to the opera, theatre, concerts, etc. Using only these questions, we are able to define three rather similar lifestyle clusters in each country, one cluster of home bodies, and two clusters of culturally active people (differences between them are related to the degree 
of activity in France, and home-centered versus outgoing activities in Norway).

Despite the fact that we are able to generate these life-style clusters, their boundaries are fuzzy when they are mapped onto the social space. Thus, in both countries we find important overlapping cultural activity groups. For France,"global capital" is associated with lifestyle, but weakly so (overlapping groups), and "capital composition" is not at all important for distinguishing between different lifestyles groups. For Norway, the activity groups are distributed so that social space is even less important than in France. Therefore, in both countries, the second dimension of the social space seems unimportant and not associated with lifestyle groups.

We did not find a strong association between social space and cultural activity groups as expected from the homology thesis. The lack of support for this thesis (in its strong interpretation) could be due to changes in France over time (nearly 50 years has passed). With a growing middle class, differences in class structures may be part of the explanation for the lack of support for the homology thesis. Another explanation, of course, is that the thesis actually never was empirically supported, except, perhaps, in Bourdieus' data, which were oversampled in urban area, thus not representative for the whole French population.

When we looked at the activity variables, we found a first latent dimension that supports the omnivore-thesis, yet we would like to suggest a slightly different interpretation of this thesis. Usually, this thesis is taken to mean that a group in the society 'eats everything', i.e. enjoy different sorts of cultural expressions, be it paintings, literature, art exhibitions, etc. Consistent across all four sets of activity variables, the full and reduced set in France, and the full and reduced set in Norway, we find the first latent dimension to be a volume component. Thus, in line with Tally Katz-Gerro (2004) we would interpret the volume dimension as an omnivorousness axis, which turns out to be - as we also saw in the analysis of social space the first latent dimension extracting most of the (positive) correlations between the variables.

Our findings of course need to be validated by other methods of analysis and other data. It does; however, seem as if only one dimension is necessary to capture social stratification in modern societies, at least when looking at lifestyle groups.
The first dimension of the social space, the volume of capital, or the "global capital", reflects the positive correlation between the social stratification variables, as measured here by the education, occupational status and income. We have seen that there is a weak association between stratification and lifestyles, but if stratification matters for lifestyles, it is the first dimension, not the "capital composition" dimension that is important. The Norwegian case is interesting, since we find no clear evidence of any social structuring of the activity groups, be it nerds, readers or home sitters (as defined by the full set of activity variables), or home sitters, cultural actives (outgoing) or cultural actives (home centered), as defined by the reduced set of activity variables. The main conclusion, for both France and Norway, is the overlapping of lifestyles groups in the social space; a finding not in line with the Boudieusian homology thesis.

We have limited our analysis to occupationally active respondents between 20-64 years of age people, thereby excluding large fractions of the populations, such as the retired, students and women outside the labour force. The students could perhaps form a life-style group on their own, if they had been included. Also, the average retirement age differ between the two countries, and in both countries we would expect respondents over 60 still in the labour market to be positively selected in terms of education. The consequences of this selection would most likely be that we - for the older age groups - mainly include the most active individuals, thus probably underestimating the number of home sitters in this group. On the other hand, many retired persons are in good health, and the fact that they have retired could imply that they have more time to be culturally active. Certainly, this topic should be investigated later.

Our analytical strategy has been explorative. We have not tried to delineate the social mechanisms generating cultural activities. This is unfortunate, since, despite ambitious theoretical elaborations on the linkages between social stratification and cultural consumption/life-styles, there is little empirical knowledge of the social mechanisms involved in these (potential) processes.

So, what is common, what is unique and what covaries between countries? We find a similar social space, and for both countries we find important overlapping of life-styles, and no differences in 
life-styles associated with the composition of capital; i.e. the second stratification dimension is not relevant for differentiating between lifestyle clusters. Looking at what is unique, we find different life-style groups in the two countries (French sport enthusiasts and Norwegian nerds), related to different questionnaires. We do not think this is due to different definitions of culture in the two countries, since in both countries sports are now part of the so-called extended culture concept. The inclusion of different questions in these surveys reminds us that we should be alert to the set-up of the questionnaires since they are formative for the data we generate. We have seen that using a traditional and limited definition of culture generates different lifestyle clusters than including a wider definition of cultural activities. I.e., we get what we look for.

Finally, looking at issues that co-vary, the population is more dispersed along capital volume in France than in Norway, and the life-styles groups are more dependent of capital volume in France than in Norway. The overlapping of the lifestyle groups therefore is greater in Norway, thus the mapping of lifestyle groups in the social space is less well designed in Norway than in France,

These findings strongly indicate that status crystallization is lower in Norway; i.e. the Norwegian stratification system is more open than the French.

\section{References}

Bennett, T. et al. 2009. Culture, Class, Distinction. London: Routledge.

Birkelund, G.E. 2006. Welfare states and social inequality. Key issues in contemporary crossnational research on social stratification and mobility. Research in Social Stratification and Mobility, vol. 24: 333-351.

Blau, P. M. 1977. Inequality and Heterogeneity: A Primitive Theory of Social Structure. New York: Free Press.

Blau, P. M. and Duncan, O.D. 1967. The American Occupational Structure. New York: John Wiley and Sons.

Bourdieu, P. [1979] 1984. Distinction: A Social Critique of the Judgement of Taste. London: Routledge \& Keagan Paul.
Chan, T.W. 2010. Social status and cultural consumption. Cambridge: Cambridge university press.

Chan, T.W. and J.H. Goldthorpe. 2007. Class and status: the conceptual distinction and its empirical relevance. American Sociological Review, vol. 72: 512-532.

Chan, T.W., Birkelund G.E., Aas A.K. and Wiborg Ø. 2011. Social Status in Norway. European Sociological Review, vol. 27: 451-468.

Coulangeon, P. and Lemel.Y.2009. "The Homology Thesis: Distinction Revisited", In K. Robson and C. Sanders (eds.): Quantifying Theory: Pierre Bourdieu. Springer, pp. 47-60.

Erikson, R. and Goldthorpe, J. 1992. The Constant Flux: A Study of class mobility in industrial societies. Oxford: Clarendon press.

Esping-Andersen, G. 1990. The Three worlds of welfare capitalism. Princeton: Princeton University Press

Ganzeboom, H., de Graaf, P. and Treiman, D. 1992. A standardized international socio-economic index for occupational status. Social Science Research, Vol. 21: 1-56.

Katz-Gerro, T. 2004. Cultural Consumption Research: Review of Methodology, Theory, and Consequence. International Review of Sociology, Vol 14: 11-29.

Lemel, Y. 2006. The social positioning of the French according to the EPCV survey. CREST Working Paper n'2006-14.

McPherson, G. 1983. Ecology of affiliation. American Sociological Review, Vol. 48:519-532.

Nyhammer, E. 2008. Mellom habitus of frihet. En kvantitativ studie av kulturelle forbruksmonstre $i$ Norge. Master Thesis. Department of Sociology and Human Geography, University of Oslo.

Peli, G. and Nooteboom, B. 1999. Market partitioning and geometry of the resource space. American Journal of Sociology, Vol. 104: 1123-1153.

Petersen, R.A. 1992. Understanding audience segmentation: from elite and mass to omnivore and univore. Poetics, vol. 21:243-258.

Prieur, A., L. Rosenlund, J. Skjøtt-Larsen. 2008. "Cultural capital today. A case study from Denmark", Poetics, 36:45-71. 
Skarpenes, O. 2007. Den legitime kulturens moralske forankring. Tidsskrift for samfunnsforskning, vol. 26: 265-275.

Weber, M. (1978, 1921). Economy and Society: An Outline of Interpretive Sociology, Berkeley: University of California press

Wright, E.O. 1985. Classes. London : Verso..

\section{Appendix Table A1. Sample characteristics}

$\begin{array}{lll} & \text { France } & \text { Norway } \\ \text { Nb. Obs } & 3744 & 993 \\ \text { Âge } & 42.4 & 39,8 \\ \text { \% Female } & 0.49 & 0,48 \\ \text { Mean(education scale) } & 10.7 & 13,2 \\ \text { Mean (status score) } & 0.0 & 0,0\end{array}$

\section{Appendix C Common set Results France}
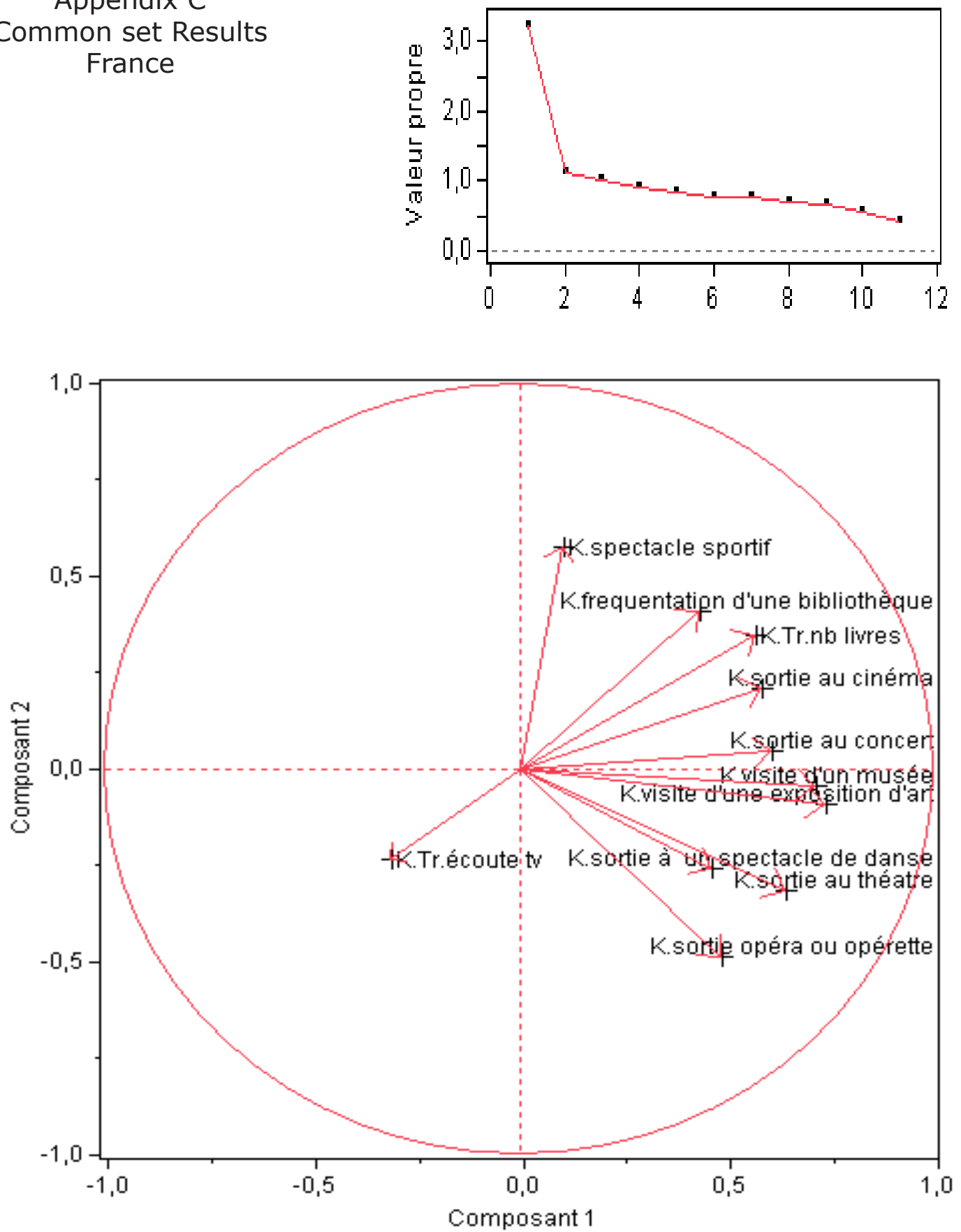
Appendix C Common set Results Norway
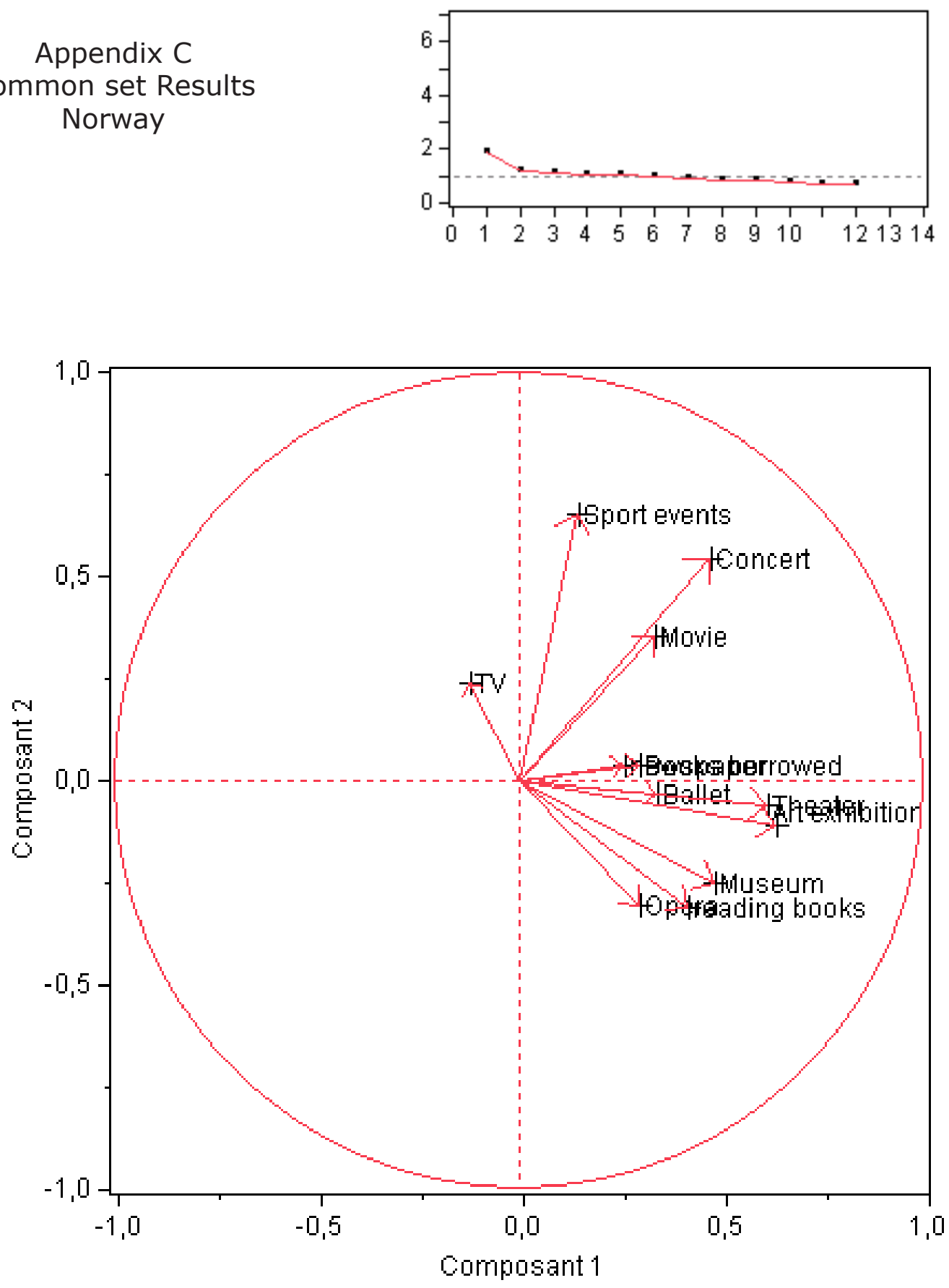
Working Papers : la liste

Hervé Le Bras, Jean-Luc Racine \& Michel Wieviorka, National Debates on Race Statistics: towards an International Comparison, FMSH-WP-2012-01, février 2012.

Manuel Castells, Ni dieu ni maître: les réseaux, FMSHWP-2012-02, février 2012.

François Jullien, L'écart et l'entre. Ou comment penser l'altérité, FMSH-WP-2012-03, février 2012.

Itamar Rabinovich, The Web of Relationship, FMSHWP-2012-04, février 2012.

Bruno Maggi, Interpréter l'agir : un défi théorique, FMSHWP-2012-05, février 2012.

Pierre Salama, Chine - Brésil : industrialisation et "désindustrialisation précoce ", FMSHWP-2012-06, mars 2012.

Guilhem Fabre \& Stéphane Grumbach, The World upside down,China's $R E D D$ and innovation strategy, FMSHWP-2012-07, avril 2012.

Joy Y. Zhang, The De-nationalization and Re-nationalization of the Life Sciences in China: A Cosmopolitan Practicality?, FMSHWP-2012-08, avril 2012.

John P. Sullivan, From Drug Wars to Criminal Insurgency: Mexican Cartels, Criminal Enclaves and Criminal Insurgency in Mexico and Central America. Implications for Global Security, FMSHWP-2012-09, avril 2012.

Marc Fleurbaey, Economics is not what you think: A defense of the economic approach to taxation, FMSH-WP-2012-10, may 2012.
Marc Fleurbaey, The Facets of Exploitation, FMSHWP-2012-11, may 2012.

Jacques Sapir, Pour l'Euro, l'heure du bilan a sonné: Quinze leçons et six conclusions, FMSHWP-2012-12, juin 2012.

Rodolphe De Koninck \& JeanFrançois Rousseau, Pourquoi et jusquioù la fuite en avant des agricultures sud-est asiatiques?, FMSH-WP-2012-13, juin 2012.

Jacques Sapir, Inflation monétaire ou inflation structurelle? Un modèle hétérodoxe bi-sectoriel, FMSH-WP-2012-14, juin 2012.

Franson Manjali, The 'Social' and the 'Cognitive' in Language. A Reading of Saussure, and Beyond, FMSH-WP-2012-15, july 2012.

Michel Wieviorka, Du concept de sujet à celui de subjectivation/dé-subjectivation, FMSHWP-2012-16, juillet 2012.

Nancy Fraser, Feminism, Capitalism, and the Cunning of History: An Introduction, FMSHWP-2012-17 august 2012.

Nancy Fraser, Can society be commodities all the way down? Polanyian reflections on capitalist crisis, FMSH-WP-2012-18, august 2012.

Marc Fleurbaey \& Stéphane Zuber, Climate policies deserve a negative discount rate, FMSHWP-2012-19, september 2012.

Roger Waldinger, La politique au-delà des frontières : la sociologie politique de l'émigration, FMSHWP-2012-20, septembre 2012.
Antonio De Lauri, Inaccessible Normative Pluralism and Human Rights in Afghanistan, FMSHWP-2012-21, september 2012.

Dominique Méda, Redéfinir le progrès à la lumière de la crise écologique, FMSH-WP-2012-22, octobre 2012.

Ibrahima Thioub, Stigmates et mémoires de l'esclavage en Afrique de l'Ouest: le sang et la couleur de peau comme lignes de fracture, FMSH-WP-2012-23, octobre 2012.

Danièle Joly, Race, ethnicity and religion: social actors and policies, FMSH-WP-2012-24, novembre 2012.

Dominique Méda, Redefining Progress in Light of the Ecological Crisis, FMSH-WP-2012-25, décembre 2012.

Ulrich Beck \& Daniel Levy, Cosmopolitanized Nations: Reimagining Collectivity in World Risk Society, FMSH-WP-2013-26, february 2013.

Xavier Richet, L'internationalisation des frmes chinoises: croissance, motivations, stratégies, FMSH-WP-2013-27, février 2013.

Alain Naze, Le féminisme critique de Pasolini, avec un commentaire de Stefania Tarantino, FMSHWP-2013-28, février 2013.

Thalia Magioglou, What is the role of "Culture" for conceptualization in Political Psychology? Presentation of a dialogical model of lay thinking in two cultural contexts, FMSH-WP-2013-29, mars 2013.

Byasdeb Dasgupta, Some Aspects of External Dimensions of Indian 
Economy in the Age of Globalisation, FMSH-WP-2013-30, april 2013.

Ulrich Beck, Risk, class, crisis, hazards and cosmopolitan solidarity/risk community - conceptual and methodological clarifications, FMSH-WP-2013-31, april 2013.

Immanuel Wallerstein, Tout se transforme. Vraiment tout?, FMSH-WP-2013-32, mai2013.

Christian Walter, Les origines du modèle de marche au hasard en finance, FMSH-WP-2013-33, juin 2013.

Byasdeb Dasgupta, Financialization, Labour Market Flexibility, Global Crisis and New Imperialism - A Marxist Perspective, FMSH-WP-2013-34, juin 2013.

Kiyomitsu Yui, Climate Change in Visual Communication: From 'This is Not a Pipe' to 'This is Not Fukushima', FMSH-WP-2013-35, juin 2013.

Gilles Lhuilier, Minerais de guerre. Une nouvelle théorie de la mondialisation du droit, FMSHWP-2013-36, juillet 2013.

David Tyfield, The Coal Renaissance and Cosmopolitized Low-Carbon Societies, FMSHWP-2013-37, juillet 2013.

Lotte Pelckmans, Moving Memories of Slavery: how hierarchies travel among West African Migrants in Urban Contexts (Bamako, Paris), FMSHWP-2013-38, juillet 2013.

Amy Dahan, Historic Overview of Climate Framing, FMSHWP-2013-39, août 2013.

Rosa Rius Gatell \& Stefania Tarantino, Philosophie et genre: Réflexions et questions sur la production philosophique féminine en Europe du Sud au $X X^{e}$ siècle (Espagne, Italie), FMSHWP-2013-40, août 2013.

Angela Axworthy The ontological status of geometrical objects in the commentary on the Elements of Euclid of Jacques Peletier du Mans (1517-1582), FMSHWP-2013-41, août 2013.

Pierre Salama, Les économies émergentes, le plongeon?, FMSHWP-2013-42, août 2013.

Alexis Nuselovici (Nouss), L'exil comme expérience, FMSHWP-2013-43, septembre 2013.

Alexis Nuselovici (Nouss), Exiliance : condition et conscience, FMSH-WP-2013-44, septembre 2013.

Alexis Nuselovici (Nouss), Exil et post-exil, FMSHWP-2013-45, septembre 2013.

Alexandra Galitzine-Loumpet, Pour une typologie des objets de l'exil, FMSH-WP-2013-46, septembre 2013.

Hosham Dawod, Les réactions irakiennes à la crise syrienne, FMSH-WP-2013-47, septembre 2013.

Gianluca Manzo, Understanding the Marriage Effect: Changes in Criminal Offending Around the Time of Marriage, FMSHWP-2013-48, GeWoP-1, octobre 2013.

Torkild Hovde Lyngstad \& Torbjørn Skarðhamar, Understanding the Marriage Effect: Changes in Criminal Offending Around the Time of Marriage, FMSH-WP-2013-49, GeWoP2, octobre 2013.

Gunn Elisabeth Birkelund \& Yannick Lemel, Lifestyles and Social Stratification: An Explorative Study of France and Norway, FMSH-WP-2013-48, GeWoP3, octobre 2013.
Franck Varenne, Chains of Reference in Computer Simulations, FMSHWP-2013-51, GeWoP-4, octobre 2013.

Olivier Galland \& Yannick Lemel, avec la collaboration d'Alexandra Frenod, Comment expliquer la perception des inégalités en France ?, FMSHWP-2013-52, GeWoP-5, octobre 2013. 


\section{Position Papers : la liste}

Jean-François Sabouret, Mars 2012 : Un an après Fukushima, le Japon entre catastrophes et résilience, FMSH-PP-2012-01, mars 2012.

Ajay K. Mehra, Public Security and the Indian State, FMSHPP-2012-02, mars 2012.

Timm Beichelt, La nouvelle politique européenne de l'Allemagne: L'émergence de modèles de légitimité en concurrence ?, FMSHPP-2012-03, mars 2012.
Antonio Sérgio Alfredo Guimarães, Race, colour, and skin colour in Brazil, FMSHPP-2012-04, july 2012.

Mitchell Cohen, Verdi, Wagner, and Politics in Opera. Bicentennial Ruminations, FMSHPP-2012-05, may 2013.

Ingrid Brena, Les soins médicaux portés aux patients âgés incapables de s'autogérer, FMSHPP-2013-06, avril 2013.
Thalia Magioglou, Refaire l'Europe ou refaire le "monde"? Un commentaire sur l'ouvrage : " Refaire l'Europe avec Jürgen Habermas ", FMSHPP-2013-07, septembre 2013.

Samadia Sadouni, Cosmopolitisme et prédication islamique transfrontalière: le cas de Maulana Abdul Aleem Siddiqui, FMSHPP-2013-08, septembre 2013.

Alexis Nuselovici (Nouss), Étudier l'exil, FMSH-PP-2013-09, septembre 2013. 